\title{
COMPARISON OF CROSS-FIELD PITTING IN FRESH, DRIED AND CHARCOALIFIED SOFTWOODS
}

\author{
T. Gerards ${ }^{1}$, F. Damblon ${ }^{2}$, B. Wauthoz ${ }^{1}$ and P. Gerrienne ${ }^{1}$
}

\begin{abstract}
SUMMARY
Cross-field pitting is one of the most reliable characters for softwood identification. During charcoalification, a range of severe qualitative and quantitative modifications may occur in cross-field pitting. As most fossil or archaeological wood remains are preserved as charcoal (fusain), the question arises whether these modifications hamper the accurate identification of some taxa. This work is a systematic biometric study of a wide range of gymnosperm cross-field pitting after experimental charcoalification. We focused on the window-like, piceoid, taxodioid, cupressoid, araucarioid and podocarpoid cross-field pitting types. Our main results are the following: 1) Cross-field pits of wood specimens dried out before charcoalification are hidden by a thin closing wall; in this case, it is often impossible to discriminate between the various types of cross-field pitting. 2) Piceoid cross-field pitting becomes taxodioid-like after charcoalification. 3) Biometric study of charred softwood cross-field pitting dimensions shows that the ratios between height and width of pit aperture and border allow us to distinguish and characterise four types of pitting (window-like, piceoid, taxodioid, cupressoid + araucarioid + podocarpoid [=CAP]). The discrimination within the CAP type requires further investigation.
\end{abstract}

Key words: Softwood, cross-field, charcoalification, piceoid, taxodioid, cupressoid.

\section{INTRODUCTION}

Charcoalification of wood results in a material chemically inert and not subject to microbial attacks. Fossil and archaeological wood remains are often preserved as charcoal. Even though the anatomical structure of charcoalified wood seems at first sight extremely well preserved, a range of physico-chemical or anatomical modifications are induced by charcoalification (Thinon 1994). Commonly observed modifications include cell wall homogenisation (Scott \& Jones 1991), formation of diagonal cracks crossing tracheid bordered pit pairs (Jones 1993), or widening of rays (Harris 1958). Identification of carbonised gymnosperm wood (softwood) is often difficult as major diagnostic features such as the shape and the size of cross-field pits are altered (Thinon 1994). For example, the pit aperture is frequently wider and more rounded in charcoalified than in fresh softwood (Thinon 1994; Gerards \& Gerrienne 2004). This sometimes results in

\footnotetext{
1) Paléobotanique, Paléopalynologie et Micropaléontologie, Département de Géologie, Université de Liège, B18 Sart Tilman, B-4000 Liège, Belgium.

2) Institut Royal des Sciences naturelles de Belgique, Rue Vautier 29, B-1000 Bruxelles, Belgium.
} 
major difficulties in wood identification. We are currently facing such difficulties in the identification of Lower Cretaceous charcoal from Belgium (work in progress at Liège University). As those Cretaceous wood pieces mostly consist of branches or branchlets, we have decided to conduct our analysis of modern material on branches.

The objectives of this work are 1) to assess to what extent the cross-field pitting of wood specimens may be modified by the charcoalification, and 2) to develop an identification method of the cross-field pitting of charcoalified specimens.

This study is a biometric approach of a wide range of gymnosperm cross-field pitting after experimental charcoalification. The study focuses on the cross-field pit types described by the IAWA Committee (2004), namely the window-like (= fenestriform), piceoid, cupressoid, taxodioid and araucarioid types. The podocarpoid cross-field type (sensu Barefoot \& Hankins 1982) was also studied. We propose an objective method, based on a few simple measures on charcoalified material that allows us to reconstruct the original shape and size of the cross-field pits of the fresh, non-carbonised wood.

\section{MATERIAL AND METHODS}

The various softwood genera were chosen according to the following criteria: 1) each type of cross-field pitting as defined by the IAWA Committee (2004) should be represented; 2) as far as possible, the chosen taxon should have a single type of cross-field type. For example, Cunninghamia R. Br. ex Rich. \& A. Rich. was rejected as it shows a variety of cross-field pitting: cupressoid, taxodioid or glyptostroboid (Greguss 1955). This second criterion was not always met, e.g. for some Pinaceae (for example Larix decidua Mill.) or those of the Taxodiaceae previously assigned to the Cupressaceae (for example Taxodium distichum (L.) Rich.). Twelve samples were collected from living specimens from the botanical garden of Liège University (Belgium; 50 $60^{\prime} \mathrm{N}$, 05 34' E): Araucaria araucana (Molina) K. Koch, Thuja plicata Donn ex D. Don, Cupressus sempervirens L., Juniperus communis L., Cryptomeria japonica (Thunb. ex L.f.) D. Don, Sequoia sempervirens (D. Don) Endl., Taxodium distichum, Cedrus libani A. Rich., Larix decidua, Picea abies (L.) Karst., Pseudotsuga menziesii (Mirb.) Franco and Pinus sylvestris L. Other samples come from dry specimens kindly provided by the Royal Museum for Central Africa (RMCA) at Tervuren (Belgium): Agathis dammara (Lamb.) Rich. \& A. Rich. (Taiwan), Podocarpus spinulosus (Sm.) R. Br. ex Mirb. (New Zealand), Callitris endlicheri (Parl.) Schltr. (Burundi), Libocedrus bidwillii Hook. f. (New Zealand), Saxothega conspicua Lindl. (Chili) and Tsuga dumosa (D. Don) Eichler (India).

One branch segment per sample, 3-5 cm long and up to $20 \mathrm{~mm}$ in diameter, was buried under $15 \mathrm{~mm}$ of fine quartz sand in order to restrict the oxygen supply. Branch segments were then charred in a furnace at $450^{\circ} \mathrm{C}$ for 1 hour. The temperature of $450^{\circ} \mathrm{C}$ was chosen because it has been shown to be frequently attained during wild fires (Scott 1989). Fresh and charcoalified specimens were cut along transverse, radial and tangential planes, and examined under a SEM JEOL JSM-5800. Scanning electron microscopy has been preferred to incident light microscopy because of the higher resolution and wider depth of focus and in order to standardise the measurements. 
Table 1. Cross-field pit type and number of pits measured for each tested species.

\begin{tabular}{llc}
\hline Species & Cross-field pit type & Number of pits measured \\
\hline Agathis dammara & Araucarioid & 13 \\
Araucaria araucana & Araucarioid & 15 \\
Callitris endlicheri & Cupressoid & 2 \\
Cedrus libani & Piceoid & 1 \\
Cryptomeria japonica & Taxodioid & 12 \\
Cupressus sempervirens & Cupressoid & 14 \\
Juniperus communis & Cupressoid & 3 \\
Larix decidua & Piceoid & 14 \\
Libocedrus bidwillii & Cupressoid & 4 \\
Picea abies & Piceoid & 8 \\
Pinus sylvestris & Fenestriform & 10 \\
Podocarpus spinulosus & Podocarpoid & 5 \\
Pseudotsuga menziesii & Piceoid & 3 \\
Saxegothaea conspicua & Cupressoid & 3 \\
Sequoia sempervirens & Taxodioid & 3 \\
Taxodium distichum & Taxodioid & 15 \\
Thuja plicata & Cupressoid & 17 \\
Tsuga dumosa & Piceoid & 2 \\
& & Total : \\
\hline
\end{tabular}

A statistical analysis was performed on 144 cross-field pits from charcoalified softwood. Investigated pits include 10 window-like (= fenestriform), 28 piceoid, 30 taxodioid, 43 cupressoid, 28 araucarioid, and 5 podocarpoid (Table 1). Pit names are those of their type before charcoalification. For each pit, variables A to D (Fig. 1a) were measured, and coefficients 1 and 2 were calculated. In order to detect a possible dependence between these six variables (A to D; 1 and 2), correlation coefficient $r$ has been calculated. Paired comparisons (Scheffé's test) between the six variables were also performed.

Fresh, non-carbonised specimens allowed easy observation and measurement of their cross-field pits in radial section on parenchyma ray cells. Both borders and pit apertures were easily seen. Measurements include width and height of cross-field pit (borders included) and apertures (A-D on Fig. 1a). Two coefficients were calculated: B/A ratio (pit aperture width/pit width ratio) is coefficient $1 ; \mathrm{D} / \mathrm{C}$ ratio (pit aperture height/pit height ratio) is coefficient 2 . The maximum pit length has been arbitrarily designated as the $\mathrm{C}$ axis (Fig. 1a).

The aperture of piceoid cross-field pits extends beyond the pit border. This character is visible in transmitted light microscopy, not in scanning electron microscopy. Therefore the coefficient 2 calculated here for that type of pit equals 1, even though the correct coefficient should be more than 1 .

Cross-field pitting of the dry samples from RMCA as observed on the ray cell wall was unclear. Pits of all samples were covered by a thin closing wall; their outline only was visible (Fig. 1b). In those samples, the pit aperture was only visible when seen on the 

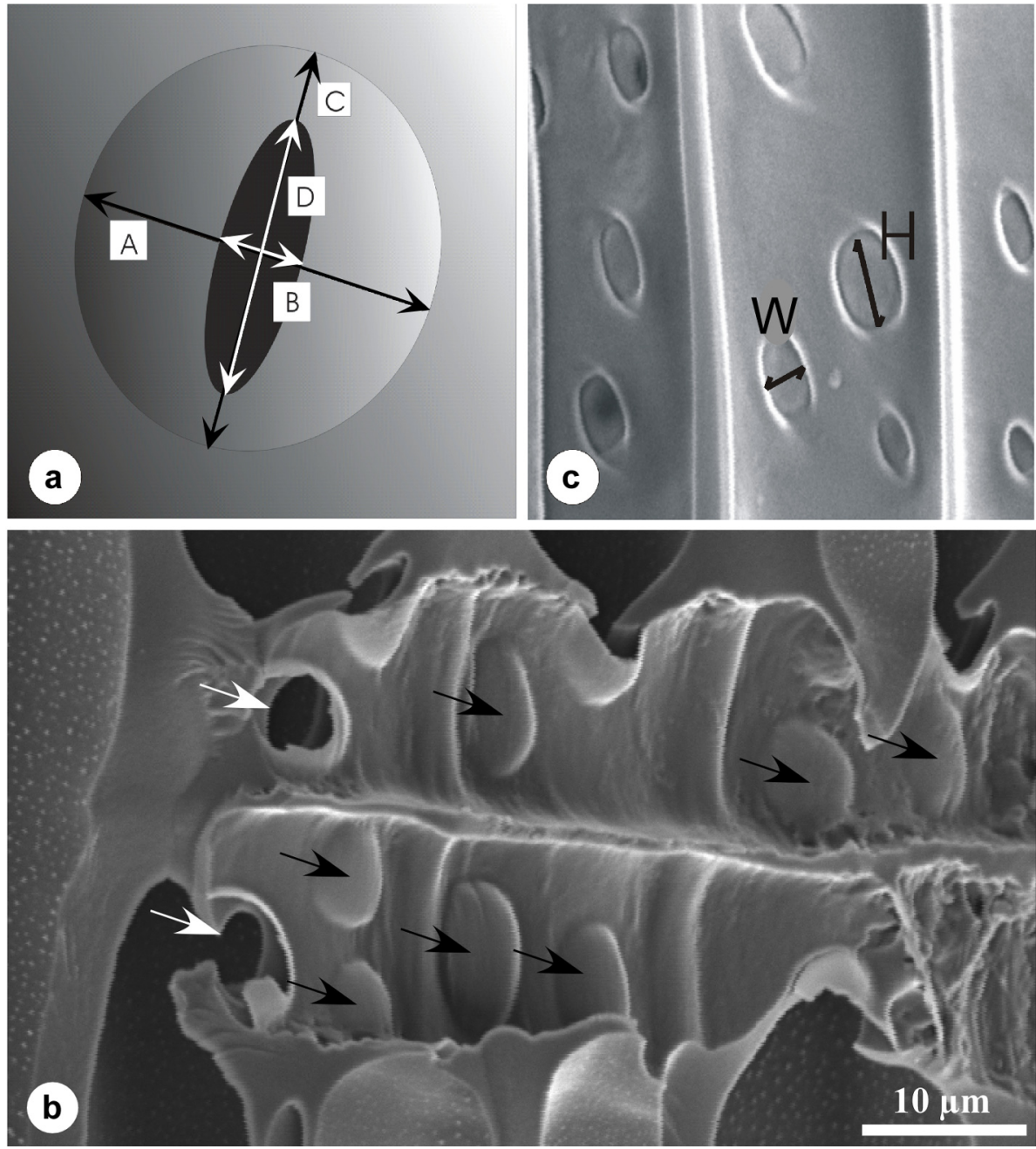

Figure 1. Cross-field pitting measurements. - a: Schematic drawing of an 'ideal' cross-field pit. A to D arrows indicate A to D variables. - b: Cross-field pits of dehydrated samples; most are covered by a thin closing wall (black arrows); in that case, only the pit outline is visible. The closing wall of two pits is broken and the pit aperture is visible (white arrows). - c: Cross-field pits of dehydrated samples as observed from the tracheid radial wall. $-\mathrm{H}$ : height, W: width; $\mathrm{A}=$ pit width, $\mathrm{B}=$ pit aperture width, $\mathrm{C}=$ pit height, $\mathrm{D}=$ pit aperture height; $\mathrm{B} / \mathrm{A}$ is coefficient 1 ; $\mathrm{D} / \mathrm{C}$ is coefficient 2 .

tracheid radial wall (Fig. 1c; see also Fig. 4c). In this case, the pit border could not be observed. The width and the height of the pit aperture only could be measured (Fig. 1c).

Another factor makes it necessary to use the size of the pit aperture in the tracheid radial wall. The cross-field pitting is best studied in earlywood (IAWA Committee 2004). When charcoal specimens are prepared for routine SEM observation, they are 
fractured along the three planes of observation. As a result of the fracture, rays of the thin-walled earlywood are sometimes pulled apart (Fig. 2a), and in this case the only way to examine cross-field pitting of earlywood is to observe the pit aperture on the tracheid radial wall (Fig. 1c, 2b).

In order to test intraspecific variations of the cross-field pit proportions, three branches (coming from three different individuals) of Picea abies (piceoid cross-field pitting), three branches of Cryptomeria japonica (taxodioid cross-field pitting), and three branches of Cupressus sempervirens (cupressoid cross-field pitting) have been included in the study. Those specimens have been prepared and observed as described above.
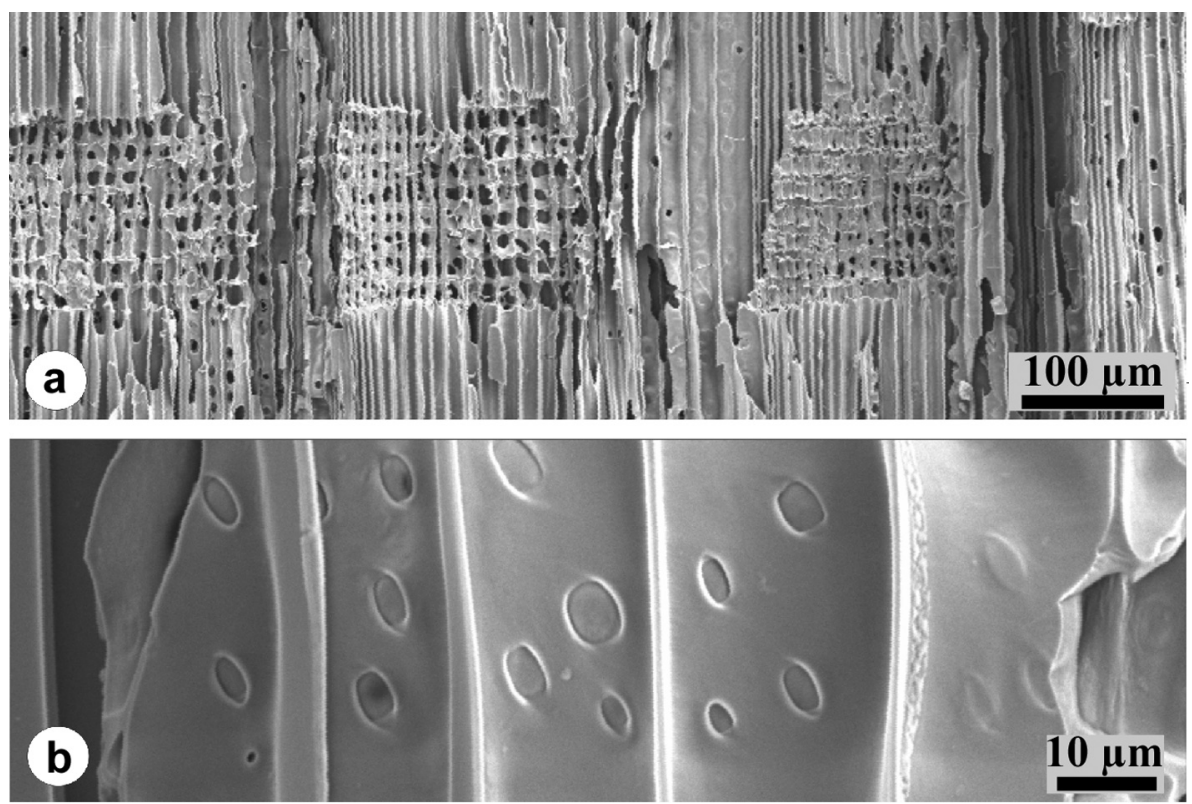

Figure 2. Carbonized softwood cross-field pitting. - a: Rays of the charcoalified thin-walled earlywood are usually pulled apart during sample preparation (Pinus sylvestris). - b: Cross-field pits as seen on the tracheid radial wall (Picea abies). - Note: $2 \mathrm{~b}$ is not an enlargement of $2 \mathrm{a}$.

\section{RESULTS AND DISCUSSION}

Fresh specimens: cross-field pits as seen on the ray cell radial wall

The variation of a range of cross-field pits from all the studied taxa possessing one of the three main pit types (piceoid, taxodioid, cupressoid) as defined by the IAWA Committee (2004), on fresh specimens (before experimental charcoalification) is shown in Figure 3. Coefficient 1 has been plotted against coefficient 2 . Three well-defined point clouds (Fig. 3) represent the three main pit types of the IAWA Committee List (2004). Clouds for piceoid and taxodioid pits almost overlap. Nevertheless, the coefficients appear discriminant, at least for the selected taxa and cross-field pitting. 


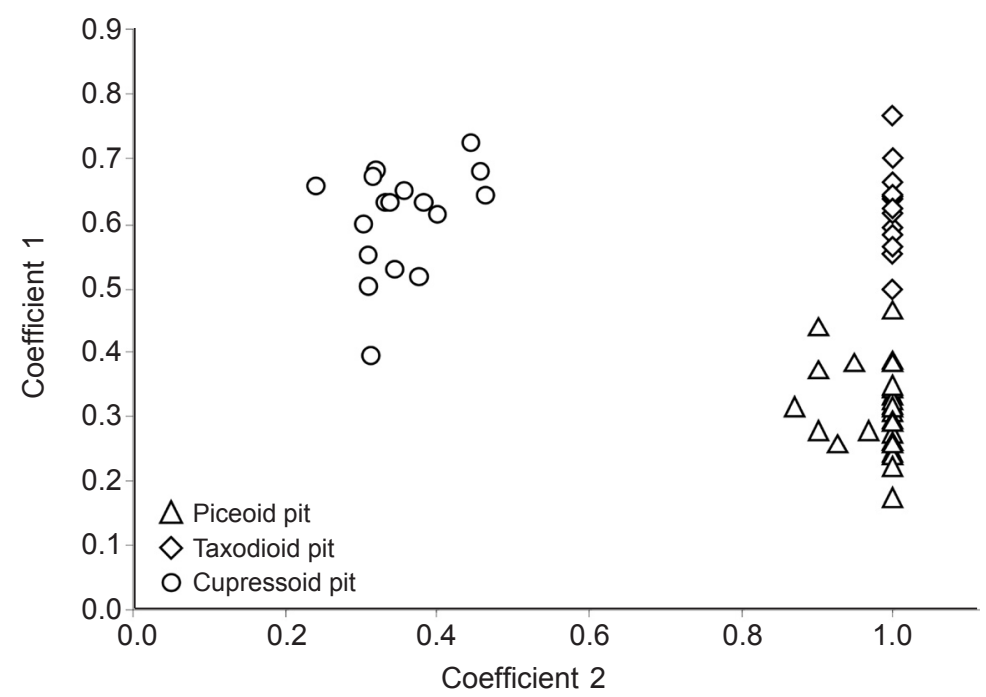

Figure 3. Coefficient 1 (pit aperture width/pit width ratio $[\mathrm{B} / \mathrm{A}]$ ) vs coefficient 2 (pit aperture height/pit height ratio $[\mathrm{D} / \mathrm{C}]$ ) of fresh softwood pits as observed in ray cell radial walls. The three cross-field pitting groups (piceoid, taxodioid, cupressoid-araucarioid-podocarpoid) are discriminated by the coefficient 1 / coefficient 2 ratio.

\begin{tabular}{|c|c|c|c|}
\hline Cross-field pit & $\mathrm{a}$ & $\mathrm{b}$ & c \\
\hline Piceoid & & & \\
\hline Taxodioid & & & \\
\hline Cupressoid & & & \\
\hline
\end{tabular}

Figure 4. Schematic drawings of a range of variations in piceoid, taxodioid and cupressoid crossfield pitting. - a: Fresh specimens; cross-field pitting as seen on the ray radial wall. - b: Charcoalified specimens; cross-field pitting as seen on the ray cell radial wall. - c: Specimens dehydrated before charcoalification; cross-field pitting as seen on the tracheid radial wall. 
Charred specimens: piceoid, taxodioid and cupressoid cross-field pits as seen on the tracheid radial wall

Schematic drawings illustrate some examples of cross-field pittings before and after experimental charring (Fig. 4). The variation after experimental charcoalification of the cross-field pitting of the same taxa (as in Fig. 3) is illustrated in Figure 5. As explained

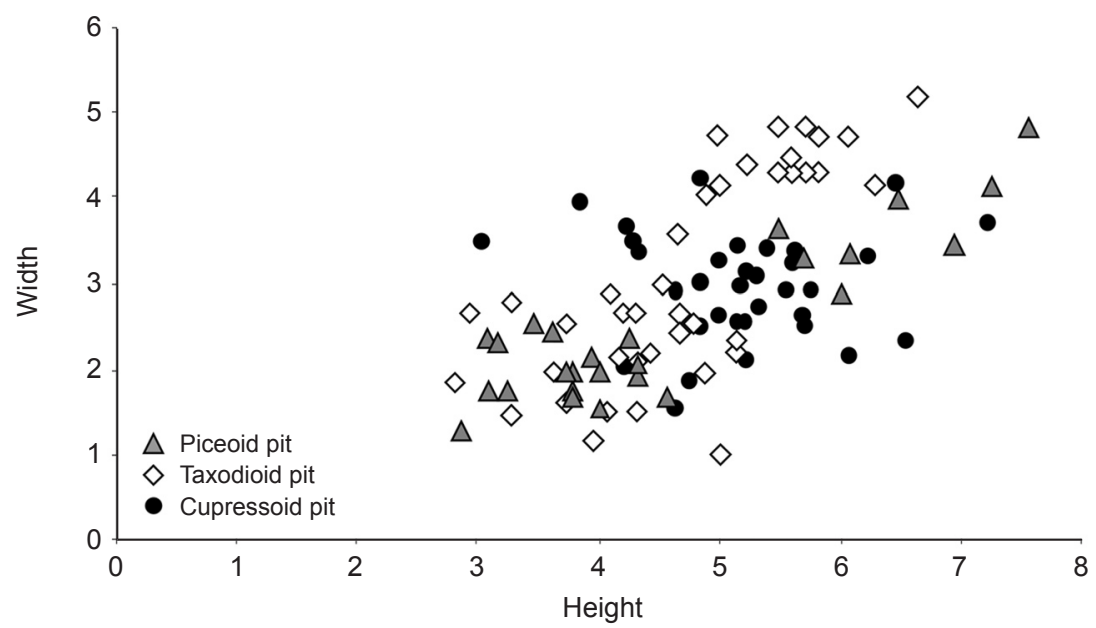

Figure 5. Height vs width of pits as observed from tracheid radial walls. These characters are not discriminative.

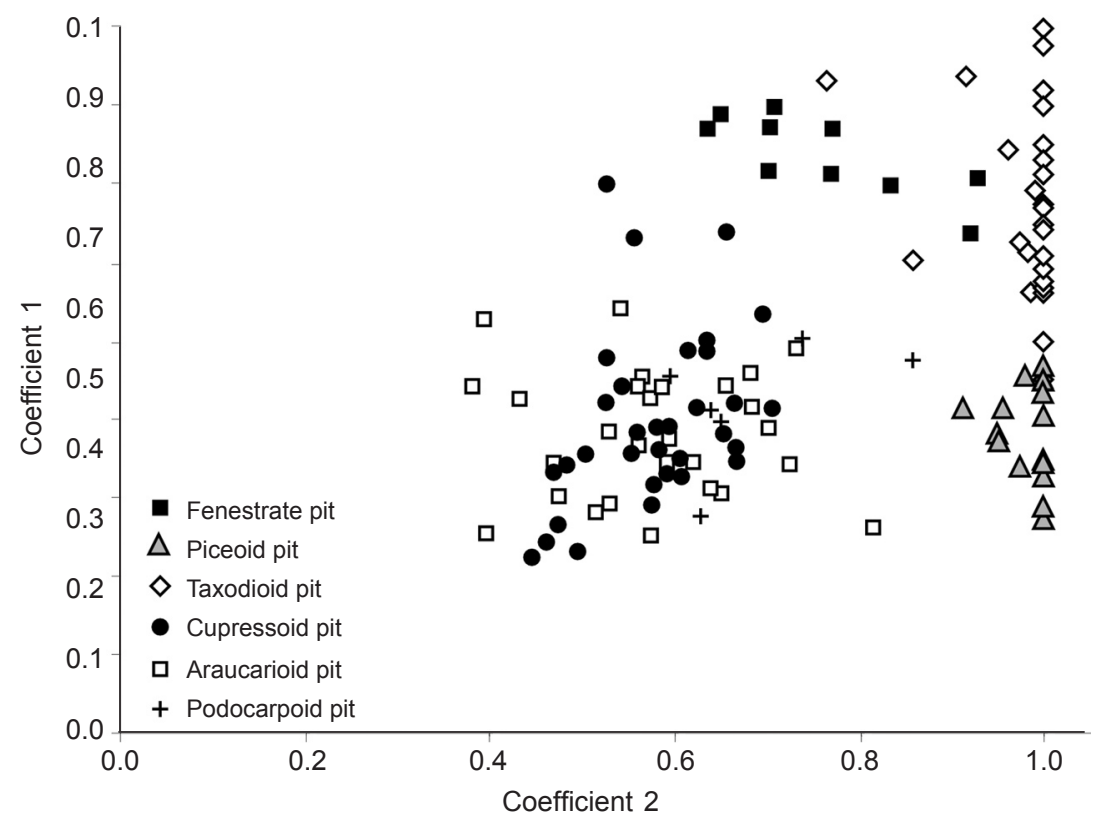

Figure 6. Coefficient 1 vs coefficient 2 of experimentally charcoalified softwood pits as observed in ray cell radial walls. Four cross-field pitting groups are distinguishable: window-like, piceoid, taxodioid, and cupressoid+araucarioid+podocarpoid. 
above, in dehydrated charcoalified woods (Fig. 1b), it is often impossible to see the crossfield pitting (Fig. 4c), and the pit aperture only can be measured on the tracheid radial wall. Figure 5 illustrates width of the piceoid, taxodioid and cupressoid cross-field pits plotted against their height. Pit names are those of their type before charcoalification. Contrary to fresh specimens (Fig. 3), the three pit types of the charcoalified wood are intermixed, and do not group together anymore. After charring, some cross-field pits, which were piceoid when fresh, become taxodioid-like. Moreover, both piceoid and taxodioid pits may become elongated (low width/length pit aperture ratio, around $0.1-0.2$ ) or almost rounded (high width/length pit aperture ratio close to 1). Consequently, the criterion "width/length cross-field pit aperture ratio" shows that piceoid and taxodioid cross-field types cannot be distinguished after charring when observed on the tracheid radial wall. After charring, cupressoid cross-field pits show a width/length cross-field pit aperture ratio that might appear slightly different as compared to the piceoid and the taxodioid types (Fig. 5). However, this criterion is not discriminant, as some charcoalified piceoid and taxodioid pits exhibit the same ratio.

\section{Charred specimens: cross-field pits as seen on the ray radial wall}

The coefficient 1 / coefficient 2 ratio for the six types of cross-field pitting after experimental charring is shown in Figure 6. As rays are often pulled apart during sample preparation, the cross-field pitting seen in the ray radial walls is very seldom observed. Window-like, piceoid and taxodioid cross-field pits are readily distinguishable, as they form discrete groups in the graph. The large size (often up to $15 \mu \mathrm{m}$ in diameter) of the window-like pits is an additional character. Piceoid and taxodioid pits are easily distinguishable from all the other types and are characterised respectively by different coefficient 1 / coefficient 2 ratios: low (around 0.5 ) for piceoid pits or high (around 0.8) for taxodioid pits. Cupressoid, araucarioid and podocarpoid types are mixed together, and cannot be discriminated. When fresh, araucarioid pits can be distinguished from the cupressoid pits because the borders of the pits of the former are adjacent. It is not possible after charcoalification, as araucarioid pit borders are no longer adjacent and look like cupressoid pits.

\section{Main results of the study}

The statistical analysis gave the following results. Coefficient $r$ between A and B is $0.92\left(r^{2}=0.85\right)$; this indicates that $\mathrm{A}$ and $\mathrm{B}$ are highly dependent. Coefficient $r$ between $\mathrm{C}$ and $\mathrm{D}$ is $0.70\left(\mathrm{r}^{2}=0.50\right)$; this means that $\mathrm{C}$ and $\mathrm{D}$ are also (but slightly less) dependent. On the contrary, coefficient 1 and 2 are independent, as shown by the low value (0.56) of $\mathrm{r}\left(\mathrm{r}^{2}=0.31\right)$. Consequently, coefficients 1 and 2 have been chosen to characterise the various cross-field pittings of charcoalified softwoods.

Paired comparisons (Scheffé's test) between the six cross-field pitting types (see above) gave the following results. Coefficient 1 allows us to discriminate between 2 groups: 1) window-like + taxodioid and 2) cupressoid + araucarioid + piceoid + podocarpoid. Coefficient 2 allows us to discriminate between 3 groups: 1) window-like, 2) piceoid + taxodioid and 3) cupressoid + araucarioid + podocarpoid. When combined, coefficients 1 and 2 allow us to distinguish 4 significantly different groups of cross-field pitting with at least $80 \%$ confidence. Those 4 groups are: 


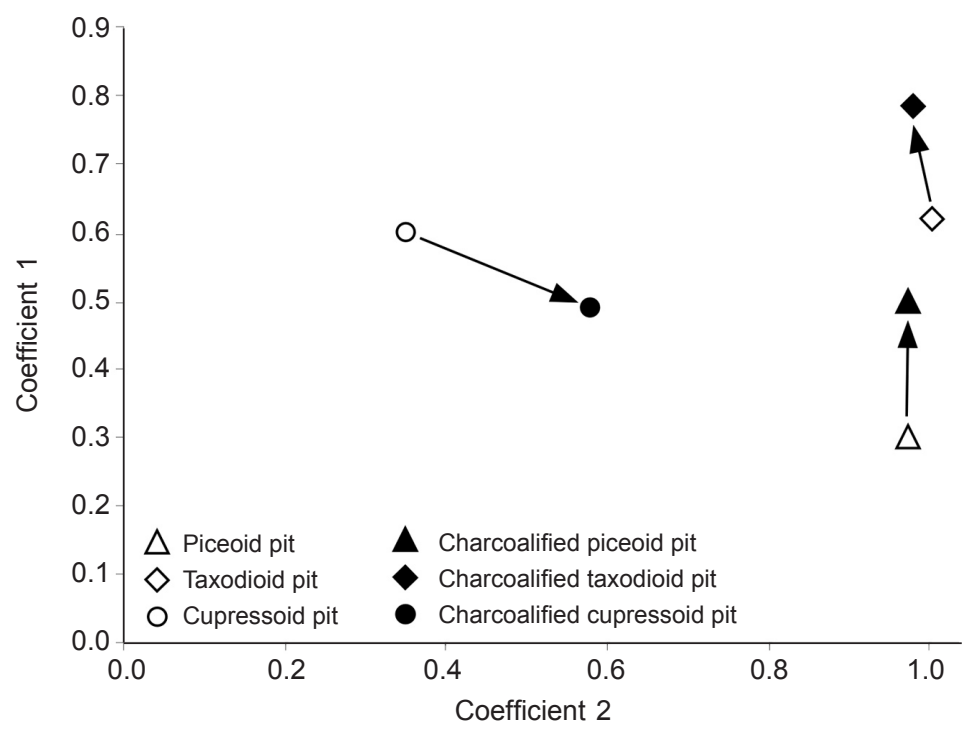

Figure 7. Modifications of coefficients 1 (pit aperture width/pit width ratio) and 2 (pit aperture height/pit height ratio) during charcoalification. Arrows indicate the transition from fresh to charcoalified condition. Note that charcoalified piceoid pits are very close to fresh taxodioid pits.

- Window-like type (as in Pinus sylvestris) (Fig. 8d): usually 1-2 large, simple or apparently simple cross-field pit(s); such large, square or rectangular pits occupying nearly the entire cross-field (IAWA Committee 2004).

- Piceoid type (as in Picea abies) (Fig. 8e): coefficient 1 between 0.47 and 0.54; coefficient 2 between 0.95 and 1.00 .

- Taxodioid type (as in Taxodium distichum or Cryptomeria japonica) (Fig. 8f): coefficient 1 between 0.75 and 0.85 ; coefficient 2 between 0.95 and 1.00 .

- CAP type (cupressoid, araucarioid and podocarpoid types) (Fig. 8a-c): coefficient 1 between 0.44 and 0.63 ; coefficient 2 between 0.53 and 0.80 .

It should be noted that 1) coefficients 1 and 2 are mean values resulting from statistical analysis, 2) pits shown in Figure 8 illustrate one ideal example chosen within a wide range of variations, and 3) slightly different pits might (see Fig. 7) have almost identical proportions or coefficients.

Coefficient 1 and coefficient 2 variations of fresh and charcoalified cross-field pitting of the piceoid, taxodioid and CAP types is shown in Figure 7. Charcoalified cross-field pitting is illustrated in Figure 8. Arrows in Figure 7 indicate the coefficient transition from fresh to charcoalified pits. In all the studied samples of piceoid and taxodioid pits, coefficient 1 (pit aperture width/pit width ratio) increases during charcoalification; this indicates that the pit aperture widens more than the border. The coefficient 1 of cupressoid pits (Fig. 8b) decreases slightly, which means that the pit border widens slightly more than the pit aperture. Charcoalified cupressoid pits as well as araucarioid 

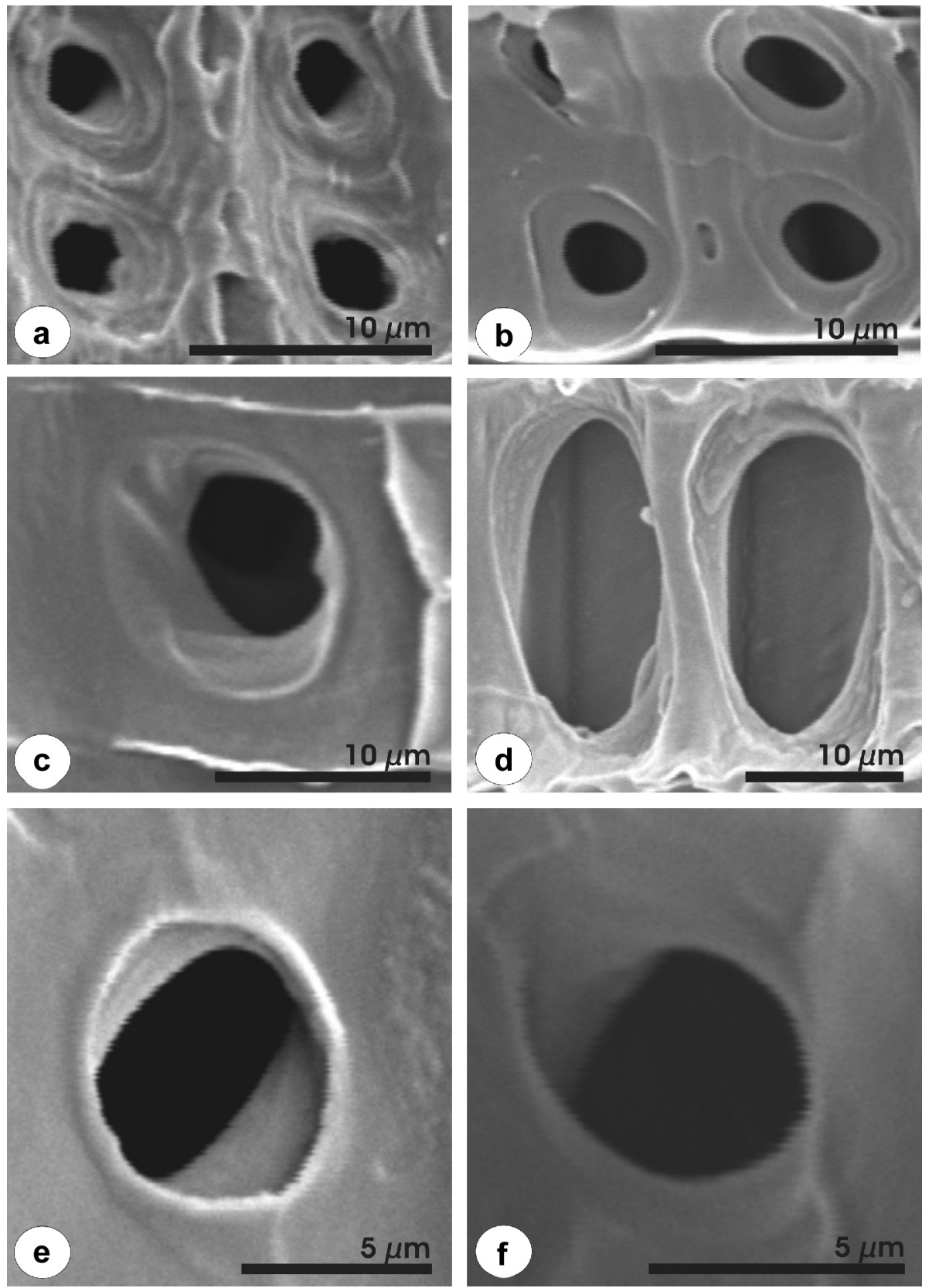

Figure 8. Carbonized softwood cross-field pitting. - a: Araucarioid pits (Araucaria araucana). - b: Cupressoid pits (Juniperus communis). - c: Podocarpoid pit (Podocarpus spinulosus). - d: Window-like (fenestriform) pits (Pinus sylvestris). - e: Piceoid pits (Pseudotsuga menziesii). - f: Taxodioid pit (Cryptomeria japonica). 
(Fig. 8a) and podocarpoid (Fig. 8c) pits can be easily distinguished from piceoid and taxodioid ones because 1) they are generally markedly distorted by carbonisation, and 2) their border remains visible around their whole outline. Coefficient 2 (pit aperture height/pit height ratio) of piceoid and taxodioid cross-field pitting is identical before and after charcoalification. To the contrary, in cupressoid cross-field pitting, coefficient 2 expands by about $15 \%$. This means that pit length elongates more than the border during charcoalification.

One of the main results of this study is also illustrated in Figure 7: charcoalified piceoid pits exhibit almost the same proportions as fresh taxodioid pits. This misleading character could result in serious misinterpretation of charcoalified wood structure and incorrect identifications.

There appears to be no significant difference between the coefficients 1 and 2 of the three branches (coming from three different individuals) of Picea abies (piceoid crossfield pitting), three branches of Cryptomeria japonica (taxodioid cross-field pitting), and three branches of Cupressus sempervirens (cupressoid cross-field pitting) (Table 2). This means that intraspecific, individual variations do not invalidate the analysis, and again demonstrate that the piceoid, taxodioid and cupressoid cross-field pittings can be discriminated on the basis of coefficients 1 and 2 .

Table 2. Mean coefficient 1 (pit aperture width/pit width ratio) and mean coefficient 2 (pit aperture height/pit height ratio) of three branches of Picea abies, Cryptomeria japonica, and Cupressus sempervirens. Each branch was collected from a different individual.

\begin{tabular}{lcccccc}
\hline \multirow{2}{*}{ Species } & \multicolumn{2}{c}{ Branch I } & \multicolumn{2}{c}{ Branch II } & \multicolumn{2}{c}{ Branch III } \\
\cline { 2 - 7 } & Coeff 1 & Coeff 2 & Coeff 1 & Coeff 2 & Coeff 1 & Coeff 2 \\
\hline Picea abies & 0.50 & 1.00 & 0.46 & 1.00 & 0.46 & 1.00 \\
Cryptomeria japonica & 0.69 & 1.00 & 0.76 & 1.00 & 0.70 & 1.00 \\
Cupressus sempervirens & 0.40 & 0.44 & 0.40 & 0.55 & 0.46 & 0.53 \\
\hline
\end{tabular}

\section{CONCLUSIONS}

Even though the anatomical structure of charred wood seems at first sight extremely well preserved, a range of modifications is induced by charcoalification. Major changes occur in cross-field pitting. The most impressive alteration occurs in piceoid cross-field pitting, which becomes taxodioid-like after charcoalification.

When wood specimens have been dried out before charcoalification, their cross-field pits are all covered by a thin closing wall, possibly the ray cell primary wall (work in progress at Liège University), with only their outline visible. This means that wood specimens without this thin closing wall in their cross-field pits have most probably been charcoalified when living or rather when fresh. Moreover, the presence of this thin closing wall makes it necessary to study the cross-field pitting as seen in the tracheid radial wall. In this case, only height and width of the pit aperture can be measured; those characters do not allow discrimination between the various cross-field pitting. 
The biometric study of cross-field pitting dimensions has shown that the ratios between height and width of pit aperture and border allow us to distinguish and characterise four types of pitting (window-like, piceoid, taxodioid, CAP). Discriminating the CAP type (cupressoid, araucarioid and podocarpoid pits) on a biometric basis needs further investigation. Our study also shows that charcoalified piceoid pits cannot be distinguished from fresh taxodioid pits. This probably often results in incorrect identification of charred fossil wood.

\section{ACKNOWLEDGEMENTS}

We warmly thank Muriel Fairon-Demaret (Liège), Hans Beeckman (Tervuren), Christopher M. Berry (Cardiff) and Ludovic Sottiaux (Liège). Philippe Gerrienne is NFSR research associate. Thomas Gerards holds a grant from FRIA.

\section{REFERENCES}

Barefoot, A.C. \& F.W. Hankins. 1982. Identification of modern and Tertiary woods. Clarendon Press, Oxford. 189 pp.

Gerards, T. \& P. Gerrienne. 2004. Étude comparative au microscope électronique à balayage du xylème secondaire de gymnospermes et angiospermes actuelles avant et après carbonisation contrôlée. Résultats préliminaires. O.F.P. Info. 29: 11-12; A2-A3.

Greguss, P. 1955. Identification of living Gymnosperms on the basis of xylotomy. Akademiai Kiadó, Budapest. 263 pp.

Harris, T.M. 1958. Forest fire in the Mezozoic. J. Ecol. 46: 447-453.

IAWA Committee. 2004. IAWA List of microscopic features for softwood identification. IAWA J. 25: 1-70.

Jones, T.P. 1993. New morphological and chemical evidence for a wildfire origin for fusain from comparison with modern charcoal. Spec. Papers Palaeont. 49: 113-123.

Scott, A.C. 1989. Observation on the nature and origin of fusain. Int. J. Coal Geol. 12: 443 475.

Scott, A.C. \& T.P. Jones. 1991. Microscopical observation of recent and fossil charcoal. Microscopy and Analysis, July: 13-15.

Thinon, M. 1994. Un système rationnel d'identification des charbons de bois pour la pédoanthracologie et l'archéoanthracologie. Bull. Soc. Linn. Prov. 45: 105-164. 